\title{
Position Number
}

National Cancer Institute

\section{Source}

National Cancer Institute. Position Number. NCI Thesaurus. Code C93628.

An integer specifying the value of an entity within a numerical sequence of other entities. 